\begin{tabular}{|c|c|c|}
\hline & International Journal of Current Research in & \\
\hline & Biosciences and Plant Biology & \\
\hline $\begin{array}{l}\text { EXCELLENT } \\
\text { PUBLISHERS }\end{array}$ & $\begin{array}{c}\text { ISSN: } 2349-8080 \text { (Online) } \bullet \text { Volume } 3 \bullet \text { Number } 11 \text { (November-2016) } \\
\text { Journal homepage: www.ijcrbp.com }\end{array}$ & 20360 \\
\hline
\end{tabular}

\title{
Some Biological Parameters of Common Carp Reared in Earthen Ponds and its Relation to their Productivity in Kirkuk Governorate, Iraq
}

\author{
Ahmed J. M. Al-Mashaykhe1\$ and Nasreen M. Abdulrahman* \\ ${ }^{1}$ Department of Animal Production, College of Agriculture, University of Kirkuk, Iraq \\ ${ }^{2}$ Department of Animal Production, College of Agriculture, University of Sulaimania, Iraq \\ *Corresponding author.
}

\section{Abstract}

This study was conducted in the laboratories of college of Agriculture, University of Kirkuk from 21/12/2015 till 21/2/2016 for assessment of common carp fish production in earthen ponds in Kirkuk governorate by study of some biological, physiological features and growth performance. Fish samples were collected from five earthen ponds in different positions in Kirkuk governorate. This study was conducted from 21/12/2015 till 21/2/2016; fish were harvested by using fishing hooks, beach seine Net and cast net. Along with the physio-biological indices, the fourth pond exceeded over other ponds in each of length-gill and weight-gill index, according to hepatosomato and gonadosomato index; the first pond differ significantly with 5.10 and 3.82 respectively, while the fifth pond exceeded significantly in condition factor. The statistical analysis appeared a positive correlation observed in the correlation between fish length and each of fish weight, gill weight, gill arch length and gill racker length.
\end{abstract}

\section{Article Info}

Accepted: 25 October 2016

Available Online: 06 November 2016

Keywords

Common carp

Earthen ponds

Productivity

\section{Introduction}

Fish biology studies in fisheries development and the availability of information about the fish gives the possibility of development in farmed and fished, classification, and sustain their economies, and so the other events pertaining to fisheries (FAO, 2012). And any step for the development of this will be useless unless it includes adequate knowledge of aspects of life for different types of fish, and the appropriate management of any water body can be followed through the comprehensive aspects of life of the types of existing fish in that flat knowledge, the subject and be important for freshwater fish because of the commercial value (FAO, 2014).
Condition factor was good indicator of fish health and the appropriate environmental conditions, but it varies with age and species, sex and state of maturity and other factors such as fed or unfed fish (Bentz,1976), and is also used to compare obesity fish on the basis of that fish in the group given to be in the best condition, it also gives a clear indication of the state of health of fish and the availability of suitable environmental conditions for living and growth in addition it shows the status of nutrition for the fish and the status of the fish and provides information regarding the abundance of food in the water bodies which it varies according to the length, sex and species, and may explain the differences in the various cases of environmental condition factor, such as the season and the quality of food and the water system in which they live fish (Wahab, 2006). 
Common carp at present one of the most important economic fish widespread in inland water bodies are the main breeding fish in Iraqi fish farms because of its achieve high production rates and resistance to clear changes in many environmental conditions and ease of cultivation and having wide food spectrum (Shawrdy, 2000). According to the importance of carp as only the rearing fish in Kirkuk and the lack of studies on fish in the province of Kirkuk, this study aimed to examine some of the biological parameters of common carp bred in ponds.

\section{Materials and methods}

Fish samples were collected from five earthen ponds and in different parts of the province of Kirkuk (first pond located at the end of Dumez area, which located southeast of Kirkuk province and provides rearing pond water through artesian wells), the second and third ponds located on the opposite side of the Wan Animal Feed Industry in Altun Kubry, which lies to the northwest of the province of Kirkuk and away from Kirkuk, about 40 $\mathrm{km}^{2}$ and from Arbil about $50 \mathrm{~km}^{2}$, and throughout little Zab River; the second pond provided with water through artesian well and the third pond from little Zab River.

The fourth pond located in the village of Bajawan, this village lies in north-west of Kirkuk, $20 \mathrm{~km}^{2}$ of the province center, and provided with water through a irrigation channel used to irrigate agricultural land and have its source from little Zab River, The fifth pond on the opposite side of Kirkuk Cement factory located 19 $\mathrm{km}^{2}$ southeast of Kirkuk, and was near to Jbela, provided with water through artesian wells.

The study continued from 21/12/2015 until 02/21/2016 by using 10-11 fish from each pond with a total number of fish were 50 fish, fish harvested in different ways, fish were preserved in cork container then fish transported directly to Animal production laboratory in the College of Agriculture, University of Kirkuk to conduct the necessary measurements and analyzes.
The below equation used for determine the studied biological parameters:

Weight gill index $=$ Gill weight $(\mathrm{g}) /$ Fish weight $(\mathrm{g}) \times 100$ Length gill index $=$ Gill length $(\mathrm{g}) /$ Fish weight $(\mathrm{g}) \times 100$ Filtration index $=$ Gill racker length $\times$ Gill arch length Condition factor $=$ Fish weight $/$ Fish Length ${ }^{3}$

Hepatosomato index $=$ Liver weight/Fish weight

Gonadosomato index = Gonad weight $/$ Fish weight

Statistical analysis was performed by applying the (CRD) to study some biological parameters of fish common carp reared in ponds using ready-statistical program, The Statistical Analysis System (SAS, 2004) and tested differences between the averages using Duncan multi-level test at $p=0.05$ level.

\section{Results and discussion}

The results of length gill index and weight gill index have a significant differences in which the forth pond in Bajawan over other treatments as shown in Table 1, filtration area was significantly higher in Domes $\left(1^{\text {st }}\right.$ pond $)$, Altun Kubry ( $2^{\text {nd }}$ pond) and in Laylan $\left(5^{\text {th }}\right.$ pond). The statistical analysis shown in Table 2, the hepatosomato and gonadosomato index of fish reared in 1st pond with 5.10 and 3.82 respectively, the condition factor was significantly high in 5th pond in Laylan ponds in all length types.

The increase in fresh liver weight that leads to the increase of Hepatosomato index in November and this may due to the good growth of this organ and protein's and lipids storage. The decrease of Hepatosomato index was a result of lowering temperatures that leads to increase of feeding activity and using the storage stuff from other organs for maintenance (Koehn, 2004). The differences in condition factor value in the present study was in the same rhythm with others and all these may be due to different factors related to fish length, age, feeding quantity, parasitic infections, time of ovulation and growth rate (Wahab, 2006).

Table 1. Some physio-biological parameters of common carp Cyprinus carpio reared in earthen ponds in Kirkuk province.

\begin{tabular}{lcll}
\hline Ponds & Length Gill index & Weight Gill index & Filtration area \\
\hline Domes $\left(1^{\text {st }}\right.$ pond) & ${ }^{\mathrm{b}} 6.92 \pm 0.80$ & ${ }^{\mathrm{b}} 2.19 \pm 0.06$ & ${ }^{\mathrm{a}} 142.53 \pm 17.13$ \\
Altun Kubry $\left(2^{\text {nd }}\right.$ pond) & ${ }^{\mathrm{bc}} 4.96 \pm 0.69$ & $\mathrm{~b} 2.02 \pm 0.12$ & $\mathrm{a} 168.40 \pm 13.61$ \\
Altun Kubry $\left(3^{\text {rd }}\right.$ pond) & ${ }^{\mathrm{d}} 1.82 \pm 0.15$ & $\mathrm{~b} 2.39 \pm 0.14$ & $\mathrm{~b} 31.04 \pm 2.46$ \\
Bajawan $\left(4^{\text {th }}\right.$ pond) & ${ }^{\mathrm{a}} 27.92 \pm 1.70$ & ${ }^{\mathrm{a}} 3.86 \pm 0.18$ & $\mathrm{~b} 38.55 \pm 3.23$ \\
Laylan $\left(5^{\text {th }}\right.$ pond) & ${ }^{\mathrm{cd}} 3.56 \pm 0.17$ & ${ }^{\mathrm{b}} 2.01 \pm 0.04$ & $\mathrm{a} 153.49 \pm 6.84$ \\
\hline
\end{tabular}

Same alphabets in superscripts between rows did not differ significantly at $p=0.05$. 
Table 2. Some biological parameters of common carp reared in earthen pond in Kirkuk province.

\begin{tabular}{|c|c|c|c|c|c|}
\hline \multirow[b]{2}{*}{ Ponds } & \multirow{2}{*}{$\begin{array}{l}\text { Hepatosomato } \\
\text { index }\end{array}$} & \multirow{2}{*}{$\begin{array}{l}\text { Gonadosomato } \\
\text { index }\end{array}$} & \multicolumn{3}{|c|}{ Condition factor according to } \\
\hline & & & Total length & Forked length & $\begin{array}{l}\text { Standard } \\
\text { length }\end{array}$ \\
\hline Domes $\left(1^{\text {st }}\right.$ pond $)$ & ${ }^{\mathrm{a}} 5.10 \pm 0.34$ & ${ }^{a} 3.82 \pm 0.46$ & $\mathrm{~b}_{2.34} \pm 0.07$ & $\mathrm{~b}_{3.13 \pm 0.08}$ & ${ }^{\mathrm{cb}} 6.66 \pm 0.16$ \\
\hline Altun Kubry ( $2^{\text {nd }}$ pond $)$ & ${ }^{\mathrm{c}} 2.07 \pm 0.20$ & ${ }^{\mathrm{c}} 1.47 \pm 0.48$ & ${ }^{b_{2}} 2.38 \pm 0.11$ & ${ }^{a b} 3.33 \pm 0.18$ & $\mathrm{~b}_{7} 7.33 \pm 0.28$ \\
\hline Altun Kubry ( $3^{\text {rd }}$ pond $)$ & $\mathrm{b}_{3.73 \pm 0.30}$ & ${ }^{a b} 3.28 \pm 0.64$ & ${ }^{c} 1.97 \pm 0.10$ & ${ }^{\mathrm{c}} 2.75 \pm 0.09$ & ${ }^{\mathrm{c}} 6.20 \pm 0.17$ \\
\hline Bajawan $\left(4^{\text {th }}\right.$ pond $)$ & $\mathrm{b}_{3.20} \pm 0.27$ & ${ }^{\mathrm{bc}} 1.74 \pm 0.48$ & ${ }^{\mathrm{d}} 1.52 \pm 0.06$ & ${ }^{\mathrm{d}} 2.21 \pm 0.07$ & ${ }^{\mathrm{d}} 4.87 \pm 0.17$ \\
\hline
\end{tabular}

Same alphabets in superscripts between rows did not differ significantly at $p=0.05$.

The determination of fish activity and growth depends on the area of respiratory gills, as the gaseous exchange between fish body and surrounding water, a location for the effective exchange of ions and gases needed by the body to maintain performance (Val et al., 2006). The results of the statistical analysis shown in Table 3 for the values of the correlation between fish length and fish weight, correlation between fish length and gill weight, and the correlation between fish length and gill arch length were a positive correlation among all ponds while a negative correlation between fish length and gill recker length as observed in Altun Kubry ( $2^{\text {nd }}$ pond).

Table 3. Correlation between fish length with each fish weight, gill weight, gill arch length, gill recker length.

\begin{tabular}{lllll}
\hline \multirow{2}{*}{ Ponds } & \multicolumn{2}{l}{ Correlation between fish length and } & \\
\cline { 2 - 5 } & Fish weight & Gill weight & Gill arch length & Gill recker length \\
\hline Domes $\left(1^{\text {st }}\right.$ pond) & 0.950 & 0.94 & 0.43 & 0.73 \\
Altun Kubry $\left(2^{\text {nd }}\right.$ pond $)$ & 0.97 & 0.87 & 0.34 & -0.51 \\
Altun Kubry $\left(3^{\text {rd }}\right.$ pond $)$ & 0.80 & 0.63 & 0.46 & 0.59 \\
Bajawan $\left(4^{\text {th }}\right.$ pond $)$ & 0.87 & 0.90 & 0.49 & 0.78 \\
Laylan $\left(5^{\text {th }}\right.$ pond $)$ & 0.83 & 0.87 & 0.49 & 0.39 \\
\hline
\end{tabular}

Gill length index was significantly high in Domes $1^{\text {st }}$ pond, Gill weight index was higher in Bajawan $\left(4^{\text {th }}\right.$ pond) while the Filtration area was significantly higher in each Domes (1st pond), Altun Kubry ( $2^{\text {nd }}$ pond) and Laylan (5 $5^{\text {th }}$ pond) with $142.53,168.40$ and 153.49 respectively as shown in Table 4.

Table 4. Some physio-biological parameters (Gill length index, Gill weight index and Filtration area) of common carp reared in earthen pond in Kirkuk province.

\begin{tabular}{llll}
\hline Ponds & Gill length index & Gill weight index & Filtration area \\
\hline Domes $\left(1^{\text {st }}\right.$ pond $)$ & ${ }^{\mathrm{a}} 6.92 \pm 0.80$ & ${ }^{\mathrm{b}} 2.19 \pm 0.06$ & ${ }^{\mathrm{a}} 142.53 \pm 17.13$ \\
Altun Kubry $\left(2^{\text {nd }}\right.$ pond $)$ & ${ }^{\mathrm{bc}} 4.96 \pm 0.69$ & ${ }^{\mathrm{b}} 2.02 \pm 0.12$ & ${ }^{\mathrm{a}} 168.40 \pm 13.61$ \\
Altun Kubry $\left(3^{\text {rd }}\right.$ pond $)$ & ${ }^{\mathrm{d}} 1.82 \pm 0.15$ & ${ }^{\mathrm{b}} 2.39 \pm 0.14$ & ${ }^{\mathrm{b}} 131.04 \pm 2.46$ \\
Bajawan $\left(4^{\text {th }}\right.$ pond $)$ & ${ }^{\mathrm{c}} 2.792 \pm 1.70$ & ${ }^{\mathrm{a}} 3.86 \pm 0.18$ & ${ }^{\mathrm{b}} 138.55 \pm 3.23$ \\
Laylan $\left(5^{\text {th }}\right.$ pond $)$ & ${ }^{\mathrm{cd}} 3.56 \pm 0.17$ & ${ }^{\mathrm{b}} 2.01 \pm 0.04$ & ${ }^{\mathrm{a}} 153.49 \pm 6.84$ \\
\hline
\end{tabular}

Same alphabets in superscripts between rows did not differ significantly at $p=0.05$.

\section{Conflict of interest statement}

Authors declare that they have no conflict of interest.

\section{References}

FAO, 2012. The State of World Fisheries and Aquaculture Food and Agriculture Organization of the United Nations, Rome.
FAO, 2014. The State of World Fisheries and Aquaculture. Opportunities and Challenges. Food and Agriculture Organization of the United Nations, Rome. 243p.

Koehn, J. D., 2004. Carp (Cyprinus carpio L.) as a power invader in Australian waterways. Freshwater Biol. 49(7), 882-894.

SAS, 2004. SAS. SAS/STAT ${ }^{\circledR} 9.1$ User's Guide, SAS Institute Inc., Cary, NC, USA.

Shawrdy, A.O., 2000. Seasonal changes of food components 
of Cyprinion Macrostomus (Heckel, 1843) and Cyprinion kais (Heckel, 1843) in Hamrin dam. M.Sc. thesis, College of Agriculture, University of Basrah.142p.

Val, A.L., De Almeida-Val, V.F., Randall, D.J., 2006. The Physiology of Tropical Fishes. Vol.21. Elsevier,
Academic Press. 642p.

Wahab, N.K., 2006. Study of some biological parameters of fish types found in Tuz Jay river, north of Iraq. Ph.D. dissertation, College of Agriculture, University of Basrah. $191 \mathrm{p}$.

How to cite this article:

Al-Mashaykhe, A. J. M., Abdulrahman, N. M., 2016. Some biological parameters of common carp reared in earthen ponds and its relation to their productivity in Kirkuk Governorate, Iraq. Int. J. Curr. Res. Biosci. Plant Biol. 3(11), 49-52. doi: http://dx.doi.org/10.20546/ijcrbp.2016.311.008 